\section{Biochar Affects Essential Nutrients of Carrot Taproots and Lettuce Leaves}

\author{
David M. Olszyk
}

U.S. Environmental Protection Agency, Center for Public Health and Environmental Assessment, Pacific Ecological Systems Division, 200 SW 35th Street, Corvallis, OR 97333

Tamotsu Shiroyama

Senior Environmental Employment Program, National Asian Pacific Center, 200 SW 35th Street, Corvallis, OR 97333

Jeffrey M. Novak, Keri B. Cantrell, Gilbert Sigua, and Donald W. Watts U.S. Department of Agriculture, Agricultural Research Service, Coastal Plains Soil, Water, and Plant Research Center, 2611 West Lucas Street, Florence, SC 29501

\section{Mark G. Johnson}

U.S. Environmental Protection Agency, Center for Public Health and Environmental Assessment, Pacific Ecological Systems Division, 200 SW 35th Street, Corvallis, OR 97333

Additional index words. Coxville soil, feedstock, human health, Norfolk soil, plants, pyrolysis temperature

\begin{abstract}
Essential nutrient concentrations in crops can affect human health. While biochar has the potential as a soil amendment to improve crop yields, it may also affect the concentrations of nutrients such as $\mathrm{Ca}, \mathrm{Fe}, \mathrm{K}, \mathrm{Mg}, \mathrm{Mn}$, and $\mathrm{Zn}$ in edible portions of crops. To better characterize effects of biochar on important human nutrients in food crops, we evaluated the effects of biochar on lettuce (Lactuca sativa L. cv. BlackSeeded Simpson) leaf and carrot [Daucus carota subsp. sativus (Hoffm.) Schübl. cv. Tendersweet] developing taproot nutrients. Plants were grown in pots in a greenhouse using sandy loam (Coxville, fine, kaolinitic, thermic Typic Paleaquults) and loamy sand (Norfolk, fine-loamy, kaolinitic, thermic Typic Kandiudults,) series soils, amended with biochar produced from four feedstocks: pine chips (PC), poultry litter (PL), swine solids (SS), and switchgrass (SG); and two blends of PC plus PL [PC/PL, $50 \% / 50 \%(55)$ and $80 \% / 20 \%(82)$ by weight]. Biochar was produced at 350,500 , and $700{ }^{\circ} \mathrm{C}$ from each feedstock. Lettuce leaf and carrot taproot total nutrient concentrations were determined by inductively coupled plasma analysis. Biochar (especially at least in part manure-based, i.e., PL, SS, 55, and 82 at nearly all temperatures) primarily decreased nutrient concentrations in lettuce leaves, with $\mathrm{Ca}, \mathrm{Mg}$, and $\mathrm{Zn}$ affected most. Carrot taproot nutrient concentrations also deceased, but to a lesser extent. Some biochars increased leaf or taproot nutrient concentrations, especially $K$. This study indicated that biochar can both decrease and increase leaf and taproot nutrient concentrations important for human health. Thus, potential effects on nutrients in plants should be carefully considered when biochar is used as a soil amendment with vegetable crops.
\end{abstract}

Access to nutritionally adequate and safe food is necessary for human welfare and economic development (Roy et al., 2006). For 2017, the UN FAO (2019) estimated that $\approx 820$ million of the world's people were undernourished. An important component of healthy food is the concentration of trace nutrients (White and Brown, 2010). Inadequacy of trace nutrients in food has been a developing human health issue (Roy et al., 2006), with $\mathrm{K}, \mathrm{Ca}, \mathrm{Mg}, \mathrm{Fe}, \mathrm{Zn}, \mathrm{I}, \mathrm{Se}$, and $\mathrm{Cu}$ most commonly inadequate in human diets (Broadley and White, 2010; White and Brown, 2010). Soils supply nutrients, which are essential to plants (Brady, 1974). Thus, soil fertility, including amendments such as fertilizer, which affect the availability of erties which affect the absorption and release of these nutrients, and affecting microbes associated with the cycling of these nutrients (Ding et al., 2016). Therefore, the availability of soil nutrients, which are necessary to improve plant mineral nutrition (White et al., 2014), could be increased by biochar.

Biochar can be produced from many different organic "waste materials" from agriculture and forestry, including materials such as poultry litter (Chan et al., 2008) and swine solids (Cantrell et al., 2012), which can cause environmental $\mathrm{N}$ pollution problems. As a result, production of biochar can help alleviate animal manure and yard waste disposal problems (Lehmann and Joseph, 2015). Furthermore, technologies are being developed whereby biochar can be produced at the source of the feedstock materials, potentially providing benefits (while also considering costs) to rural economies (Joseph, 2009).

The source of the feedstock and pyrolysis temperature can greatly affect its nutrient composition. Cellulosic-based feedstocks such as straw or wood produce biochars that are usually low in ash (Novak et al., 2014) and, hence, low in major nutrients such as $\mathrm{Ca}$, $\mathrm{Mg}, \mathrm{K}$, and trace nutrients such as $\mathrm{Fe}, \mathrm{Zn}$, and Mn (Ippolito et al., 2015; Novak et al., 2013). In contrast, manure-based feedstocks produce biochars that are high in ash and major and trace nutrients (Ippolito et al., 2015; Novak et al., 2013, 2014). When a feedstock comes from a source where nutrients are purposely added at some stage during its production, these can be reflected by high concentrations in the resulting biochar. For example, when swine are fed $\mathrm{Zn}$ as a supplement (Sistani and Novak, 2006), the biochar produced from swine waste can have high $\mathrm{Zn}$ concentrations (Novak et al., 2015). Increasing the pyrolysis temperature will drive off more volatile compounds and nutrients such as $\mathrm{O}, \mathrm{H}$, and $\mathrm{N}$, thus increasing the relative concentration of ash and associated nutrients in the biochar (Ippolito et al., 2015; Novak et al., 2014).

Because of biochar's potential to add nutrients to the soil either directly, or indirectly by affecting soil properties influencing nutrient bioavailability (Chan and $\mathrm{Xu}, 2009$ ), biochar can affect the concentration of nutrients in plants. A meta-analysis indicated that biochar generally increased plant leaf $\mathrm{K}$ concentrations across a variety of crops (Biederman and Harpole, 2013). For example, in maize leaf, $\mathrm{K}$ increased with peanut hull biochar (Gaskin et al., 2010) and eucalyptus biochar (Butnan et al., 2015), while willow wood biochar had no effect on maize leaf K (Agegnehu et al., 2016). Butnan et al. (2015) reported decreases in maize leaf $\mathrm{Ca}$, $\mathrm{Mg}$, and $\mathrm{Mn}$ with some eucalyptus biochar treatments. Masud et al. (2014) reported increased plant uptake of $\mathrm{K}$ and $\mathrm{Ca}$, with biochar application on soybeans. However, while current literature indicates a variety of plant nutrient responses to biochar, additional studies are needed to better understand the effect of biochar applications elements that are important for the nutritional value of food 
crops (Martin et al., 2011; White and Brown, 2010).

Despite the commercial support for use of biochar as a soil amendment and availability of different products (e.g., KIS Organics, 2019; Pleasant, 2009; Wakefield Biochar, 2019; White, 2018), there has been relatively little research on both the potential positive or negative effects on horticultural crops. For example, biochar has been considered as an amendment to growing media such as peat replacement (Blok et al., 2017) or as a substrate in a soilless hydroponic system for tomato production (Dunlop et al., 2015).

The general focus for biochar and metals has been in terms of either excess heavy metals due to biochar feedstocks and production techniques (Subedi et al., 2017), and the potential use of biochar to reduce potentially high concentrations of toxic heavy metals such as $\mathrm{Cd}$ or $\mathrm{Pb}$ in plants, which could adversely affect human health (Peng et al., 2018). For example, application of PL or SS biochar, along with compost, reduced $\mathrm{Cd}$ and $\mathrm{Zn}$ concentrations in a metal-contaminated mine soil and switchgrass roots and shoots, which were associated with increased root and shoot growth (Novak et al., 2019). Addition of cassava stem biochar to a $\mathrm{Cd}$ - and Zn-contaminated soil reduced the bioavailability of both nutrients and concentration of $\mathrm{Zn}$ but increased the concentration of $\mathrm{Cd}$ in Vigna radiata L. roots and shoots (Prapagdee et al., 2014). Based on a meta-analysis, Chen et al. (2018) estimated an average $17 \%$ decrease in plant $\mathrm{Zn}$ with biochar application across a wide variety of conditions. Because some of these trace nutrients such as $\mathrm{Zn}$ and

Received for publication 13 Aug. 2019. Accepted for publication 19 Nov. 2019.

Published online 17 January 2020.

We thank Dr. Daniel Sullivan of Oregon State University for advice concerning this manuscript; Dr. Maliha Nash and Dr. E. Henry Lee, U.S. EPA, for assistance in experimental design and statistical analysis; Dr. James Ippolito, USDA Agricultural Research Service, for assistance with total nutrient concentration analysis; and Mr. Leon Reece, National Asian Pacific Center Senior Environmental Employment Program, for assistance in monitoring and maintaining greenhouse conditions. The information in this document has been funded in part by the U.S. Environmental Protection Agency under contract number EP-D-11-027 to CSS-Dynamac Corporation.

The views expressed in this article are those of the authors and do not necessarily represent the views or policies of the U.S. Environmental Protection Agency or the U.S. Department of Agriculture. Any mention of trade names, products, or services does not imply an endorsement by the U.S. government, or the U.S. Environmental Protection Agency (EPA), or the U.S. Department of Agriculture (USDA). The EPA and the USDA do not endorse any commercial products, services, or enterprises. The USDA is an equal opportunity employer.

D.M.O. is the corresponding author. E-mail: olszyk. david@epa.gov.

This is an open access article distributed under the CC BY-NC-ND license (https://creativecommons. org/licenses/by-nc-nd/4.0/).
Mn are also essential for humans, any reduction of normally low concentrations in soils due to biochar could also adversely affect human health.

There have been a few reports in the biochar literature specifically relating to its potential beneficial effects on trace nutrients and human health, by increasing the supply of these nutrients to crops. For example, acidified (with $\mathrm{S}$ ) maize cob biochar increased the concentrations of $\mathrm{Fe}, \mathrm{K}, \mathrm{Mn}$, and $\mathrm{Zn}$, and to a lesser extent, $\mathrm{Mg}$ and $\mathrm{Ca}$ (in one case biochar decreased $\mathrm{Ca}$ ), in quinoa seed for plants growing under different soil stress conditions (Ramzani et al., 2017). While eucalyptus twig biochar by itself had no effect on rice grain $\mathrm{Fe}$ concentration, the biochar did enhance the increase in concentrations of these nutrients when $\mathrm{Fe}$ fertilizer was also used to biofortify the crop with Fe (Ramzani et al., 2016a). In a study with biosolids and biosolids plus biochar (made from Pinus radiata chips) in combination, Gartler et al. (2013) found increased extractable soil $\mathrm{Zn}$ concentrations and the concentrations of $\mathrm{Zn}$ in the edible portions of several crops, including lettuce leaves and carrot taproots. The biosolids were the source of the $\mathrm{Zn}$; and while biochar by itself had no effect on $\mathrm{Zn}$ concentrations in nearly all crops, biochar by itself increased the $\mathrm{Zn}$ concentration in radish bulbs (Gartler et al., 2013). When biochar was in combination with biosolids it further increased the concentration of $\mathrm{Zn}$ in lettuce leaves but decreased the concentration relative to biosolids alone in radish leaves and bulbs (Gartler et al., 2013). Biochar produced from macroalgae grown in industrial wastewater increased the concentration of $\mathrm{Ca}, \mathrm{Mg}$, $\mathrm{K}$, and Mo in radish roots (Roberts et al., 2015), suggesting that high nutrient concentration biochars could be used to supply plants with nutrients essential for human health.

However, Hartley et al. (2016) reported that woody material from green waste composting facilities, and rhododendron and softwood all reduced $\mathrm{Cu}, \mathrm{Zn}, \mathrm{Fe}$, and $\mathrm{Mn}$ uptake into wheat grains. In other studies, Sorrenti et al. (2016) found that kiwifruit had $\mathrm{Fe}$ chlorosis symptoms when grown in biochar amended soil, while Moreno-Jiménez et al. (2016) reported no effect of oak biochar on barley grain $\mathrm{Cu}$ and $\mathrm{Zn}$ concentrations. Thus, the relationship between biochar and trace nutrient concentrations in crops is complex, and there have been few suggestions that changes in crop nutrient concentrations solely due to biochar additions could adversely affect mineral nutrients in food for human consumption.

Thus, we conducted a study which indicated if amending soils with biochar could have beneficial or detrimental effects on the concentrations of key inorganic nutrients for human nutrition in the edible portions of crops. The focus was on the effects of different biochars on concentrations of major $(\mathrm{Ca}$, $\mathrm{K}, \mathrm{Mg}$ ) and minor ( $\mathrm{Fe}, \mathrm{Mn}, \mathrm{Zn}$ ) plant nutrients contained in lettuce leaves and carrot taproots. Lettuce is a food source for $\mathrm{Ca}, \mathrm{Fe}$, and K (Noumedem et al., 2017), while carrot taproots are an important source of $\mathrm{K}, \mathrm{Mg}$,

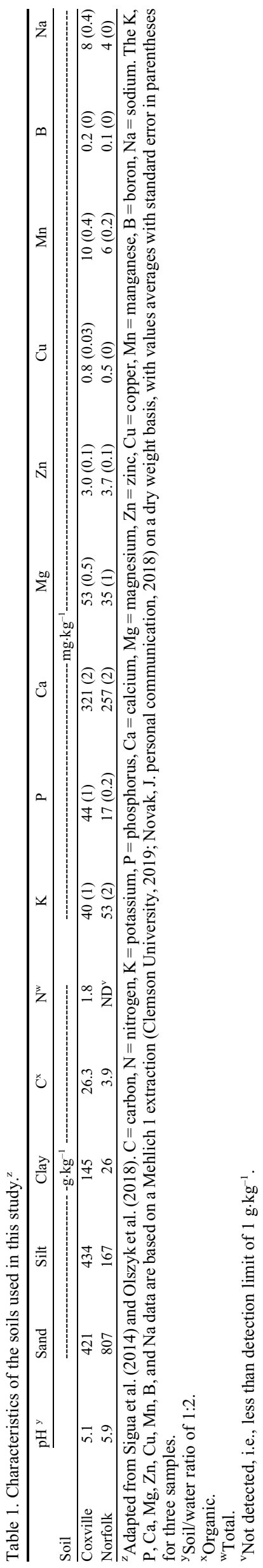


Table 2. The pH, electrical conductivity (EC), and extractable phosphorus concentrations (EP) of biochars used in this study. ${ }^{\mathrm{z}}$

\begin{tabular}{|c|c|c|c|c|c|c|c|c|c|}
\hline Feedstock & ${ }^{\circ} \mathrm{C}$ & $\mathrm{pH}$ & $\mathrm{EC}\left(\mathrm{mS} \cdot \mathrm{cm}^{-1}\right)$ & $\mathrm{EP}\left(\mathrm{mg} \cdot \mathrm{L}^{-1}\right)$ & Feedstock & ${ }^{\circ} \mathrm{C}$ & $\mathrm{pH}$ & $\mathrm{EC}\left(\mathrm{mS} \cdot \mathrm{cm}^{-1}\right)$ & $\mathrm{EP}\left(\mathrm{mg} \cdot \mathrm{L}^{-1}\right)$ \\
\hline Poultry litter & 350 & $8.73(0.01)$ & $16.45(0.07)$ & $81.3(2.3)$ & Swine solids & 350 & $6.94(0.01)$ & $3.14(0.01)$ & $181.4(8.2)$ \\
\hline Poultry litter & 500 & $9.76(0.004)$ & $18.94(0.07)$ & $61.0(0.9)$ & Swine solids & 500 & $7.80(0.03)$ & $2.98(0.01)$ & $195.2(0.6)$ \\
\hline Poultry litter & 700 & $10.30(0.01)$ & $20.39(0.05)$ & $16.4(0.2)$ & Swine solids & 700 & $8.74(0.09)$ & $1.64(0.04)$ & $136.8(3.1)$ \\
\hline PC:PL 55 & 350 & $7.68(0.01)$ & $8.59(0.04)$ & 201.4 (1.9) & Pine chips & 350 & $5.74(0.03)$ & $0.37(0.003)$ & $7.2(0.2)$ \\
\hline PC:PL 55 & 500 & $9.99(0.01)$ & $8.99(0.04)$ & $100.1(2.3)$ & Pine chips & 500 & $7.57(0.01)$ & $0.42(0.004)$ & $3.6(0.2)$ \\
\hline PC:PL 55 & 700 & $10.44(0.005)$ & $9.92(0.12)$ & $67.4(1.6)$ & Pine chips & 700 & $8.92(0.01)$ & $0.51(0.01)$ & $0.04(0.01)$ \\
\hline PC:PL 82 & 350 & $7.69(0.01)$ & $2.54(0.01)$ & $195.0(1.6)$ & Switchgrass & 350 & $5.76(0.05)$ & $0.33(0.003)$ & $13.6(0.5)$ \\
\hline PC:PL 82 & 500 & $9.66(0.003)$ & $3.04(0.07)$ & $104.2(1.8)$ & Switchgrass & 500 & $8.38(0.02)$ & $0.79(0.01)$ & $44.7(0.2)$ \\
\hline PC:PL 82 & 700 & $10.08(0.002)$ & $3.78(0.02)$ & $60.3(1.6)$ & Switchgrass & 700 & $9.56(0.01)$ & $0.80(0.003)$ & $30.2(0.1)$ \\
\hline
\end{tabular}

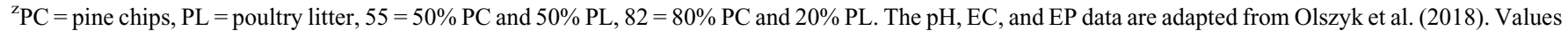
are averages with standard error in parentheses for four samples.

Table 3. Total elemental concentrations of biochars used in this study. ${ }^{\mathrm{z}}$

\begin{tabular}{|c|c|c|c|c|c|c|c|c|c|c|c|}
\hline \multirow[b]{2}{*}{ Feedstock } & \multirow[b]{2}{*}{${ }^{\circ} \mathrm{C}$} & $\mathrm{Al}$ & $\mathrm{Ca}$ & $\mathrm{Fe}$ & $\mathrm{K}$ & $\mathrm{Mg}$ & $\mathrm{P}$ & $\mathrm{S}$ & $\mathrm{Cu}$ & Mn & $\mathrm{Zn}$ \\
\hline & & \multicolumn{7}{|c|}{----- } & \multicolumn{3}{|c|}{----------------- mg.kg ${ }^{-1}$---------------- } \\
\hline Poultry litter & 350 & 0.4 & 35 & 2.8 & 56 & 12 & 25 & 9.8 & 225 & 868 & 911 \\
\hline Poultry litter & 500 & 1.1 & 47 & 5.4 & 70 & 17 & 34 & 11.6 & 261 & 1125 & 1233 \\
\hline Poultry litter & 700 & 1.4 & 50 & 7.0 & 77 & 18 & 35 & 9.8 & 361 & 1171 & 1241 \\
\hline PC:PL 55 & 350 & 0.4 & 21 & 1,8 & 34 & 8 & 13 & 5.0 & 140 & 501 & 552 \\
\hline PC:PL 55 & 500 & 0.7 & 26 & 4.8 & 36 & 9 & 18 & 4.8 & 221 & 627 & 617 \\
\hline PC:PL 55 & 700 & 0.8 & 27 & 3.3 & 43 & 9 & 18 & 3.0 & 177 & 638 & 490 \\
\hline PC:PL 82 & 350 & 0.3 & 9 & 2.6 & 12 & 3 & 5 & 1.5 & 52 & 220 & 202 \\
\hline PC:PL 82 & 500 & 0.4 & 12 & 3.3 & 16 & 4 & 6 & 1.4 & 64 & 284 & 272 \\
\hline PC:PL 82 & 700 & 0.3 & 10 & 8.0 & 14 & 3 & 5 & $<0.1$ & 237 & 238 & 142 \\
\hline Swine solids & 350 & 1.0 & 37 & 5.8 & 13 & 31 & 50 & 10.8 & 1920 & 1855 & 5010 \\
\hline Swine solids & 500 & 1.6 & 53 & 9.1 & 21 & 42 & $>50$ & 10.1 & 2384 & 2545 & 6836 \\
\hline Swine solids & 700 & 2.2 & 56 & 11.6 & 21 & 44 & $>50$ & 7.2 & 2628 & 2717 & 6790 \\
\hline Pine chips & 350 & 0.3 & 3 & 0.5 & 2 & 0.9 & 0.3 & $<0.1$ & 9 & 82 & 36 \\
\hline Pine chips & 500 & 0.4 & 5 & 1.6 & 3 & 1.2 & 0.6 & $<0.1$ & 36 & 125 & 78 \\
\hline Pine chips & 700 & 0.2 & 3 & 2.7 & 2 & 0.4 & 0.2 & $<0.1$ & 64 & 65 & 26 \\
\hline Switchgrass & 350 & $<0.1$ & 3 & 0.5 & 2 & 1.9 & 0.8 & 0.7 & 11 & 49 & 28 \\
\hline Switchgrass & 500 & $<0.1$ & 4 & 1.4 & 4 & 2.5 & 1.5 & 0.7 & 44 & 93 & 63 \\
\hline Switchgrass & 700 & $<0.1$ & 3 & 2.9 & 4 & 1.0 & 0.6 & $<0.1$ & 93 & 55 & 24 \\
\hline
\end{tabular}

${ }_{\mathrm{z}}$ Values are on a dry weight basis. $\mathrm{Al}=$ aluminum, $\mathrm{Ca}=$ calcium, $\mathrm{Fe}=$ iron, $\mathrm{K}=$ potassium, $\mathrm{Mg}=$ magnesium, $\mathrm{P}=$ phosphorus, $\mathrm{S}=$ sulfur, $\mathrm{Cu}=$ copper, $\mathrm{Mn}=$ manganese, $\mathrm{Zn}=$ zinc, $\mathrm{PC}=$ pine chips, $\mathrm{PL}=$ poultry litter, $55=50 \% \mathrm{PC}$ and $50 \% \mathrm{PL}, 82=80 \% \mathrm{PC}$ and $20 \% \mathrm{PL}$. The nutrient data are for one sample with analysis details given in the methods section of this article.

and Mn (Bjarnadottir, 2019; da Silva Dias, 2014). In addition, because biochar characteristics should be tailored to particular soil problems (Novak and Busscher, 2012), we evaluated biochar effects using two South Carolina coastal plain soils, the Coxville and Norfolk series.

\section{Materials and Methods}

Soils and biochar. Two agricultural soils used in this experiment were collected from a field at the Clemson University Pee Dee Research and Education Center farm in the Coastal Plain region of South Carolina near Florence, SC. The soils were the sandy loam (fine, kaolinitic, thermic Typic Paleaquults) Coxville Series and loamy sand (fine-loamy, kaolinitic, thermic Typic Kandiudults) Norfolk Series. Soil characteristics are summarized in Table 1 and are based on J. Novak, personal communication (2018), Olszyk et al. (2018), and Sigua et al. (2014) for the nutrients $\mathrm{B}, \mathrm{Ca}, \mathrm{Cu}, \mathrm{K}, \mathrm{Mg}, \mathrm{Mn}, \mathrm{Na}, \mathrm{P}$, and $\mathrm{Zn}$. Analysis for these nutrients was by Clemson University (2019) and used the Mehlich 1 extraction procedure followed by ICP analysis. Overall, the Coxville soil had a slightly lower $\mathrm{pH}$ and higher $\mathrm{C}$ and $\mathrm{N}$ concentrations than the Norfolk soil (N not detectable for the Norfolk soil at a limit of 1 $\mathrm{g} \cdot \mathrm{kg}^{-1}$ ). The $P$ value was over twice as high for the Coxville than for the Norfolk soil, with values for the other elements varying between the two soils.

Four biochar feedstocks were used: switchgrass straw (Panicum virgatum) (SG), loblolly pine chips (Pinus taeda) (PC), swine solids (SS), and poultry litter (PL). There were also two blends of PC and PL: $50 \%$ PC and $50 \%$ PL (55), and $80 \%$ PC and 20\% PL (82) by weight. Biochars were produced as indicated in Novak et al. (2013), Novak et al. (2014), and Olszyk et al. (2018). For mixtures, PC and PL feedstocks were combined before being made into pellets. Feedstocks and blends were formed into cylindrical pellets using a PP220 pellet mill (Pellet Pros., Inc., Davenport, IA) equipped with a 6-mm die as described by Novak et al. (2014). Resulting pellets were sieved using a 4-mm sieve to eliminate fine material. Pellets retained on the 4-mm sieve were used in the study. Pellets for each feedstock were then was pyrolyzed at a low $\left(350{ }^{\circ} \mathrm{C}\right)$, medium $\left(500^{\circ} \mathrm{C}\right)$ and high $\left(700^{\circ} \mathrm{C}\right)$ temperature using a furnace-retort system (Lindberg/MPH, Riverside, MI) for 1 to $2 \mathrm{~h}$ (Novak et al., 2013), depending on sample size.

Soil and biochar pellets from the appropriate feedstock or blend were combined for each biochar treatment as described by Novak et al. (2014). For a $1 \%$ mixture of soil and biochar, a target of $450 \mathrm{~g}$ of soil was weighed into a bag and then a target of $4.5 \mathrm{~g}$ of biochar was added. Each bag was then thoroughly mixed by hand, spread, and placed in the pots.

Details concerning properties of the biochar used in this study are found in Olszyk et al. (2018), Novak et al. (2013), Novak et al. (2014), and Sigua et al. (2014); and details are summarized in Tables 2 and 3. The biochar $\mathrm{pH}$, electrical conductivity (EC), and extractable phosphorus (EP) values were measured for four samples per biochar as discussed previously in Olszyk et al. (2018). In brief, $\mathrm{pH}$ and EC were measured using a $2: 1$ water to biochar or soil ratio $(\mathrm{v} / \mathrm{v})$ with MilliQ water. The EP was measured spectrophotometrically (Olsen and Sommers, 1982). As indicated earlier (Olszyk et al., 2018), biochar $\mathrm{pH}$ was highest for PL, 82 and 55, and lower for SS, PC, and SG (Table 2). The EC was highest with PL, followed by 55; with 82 and SS moderate, and PC and SG lowest. The EP was highest with SS, 55 and 82; with PL moderate, and PC and SG low. For a particular feedstock or blend, the $\mathrm{pH}$ and EC tended to increase with increasing pyrolysis temperature, while EP deceased with increasing temperature.

Biochar total nutrient (i.e., elemental $\mathrm{Al}$, $\mathrm{Ca}, \mathrm{Cu}, \mathrm{Fe}, \mathrm{K}, \mathrm{Mg}, \mathrm{Mn}, \mathrm{P}, \mathrm{S}$, and $\mathrm{Zn}$ ) concentrations were measured for one sample by a commercial laboratory (Bureau 

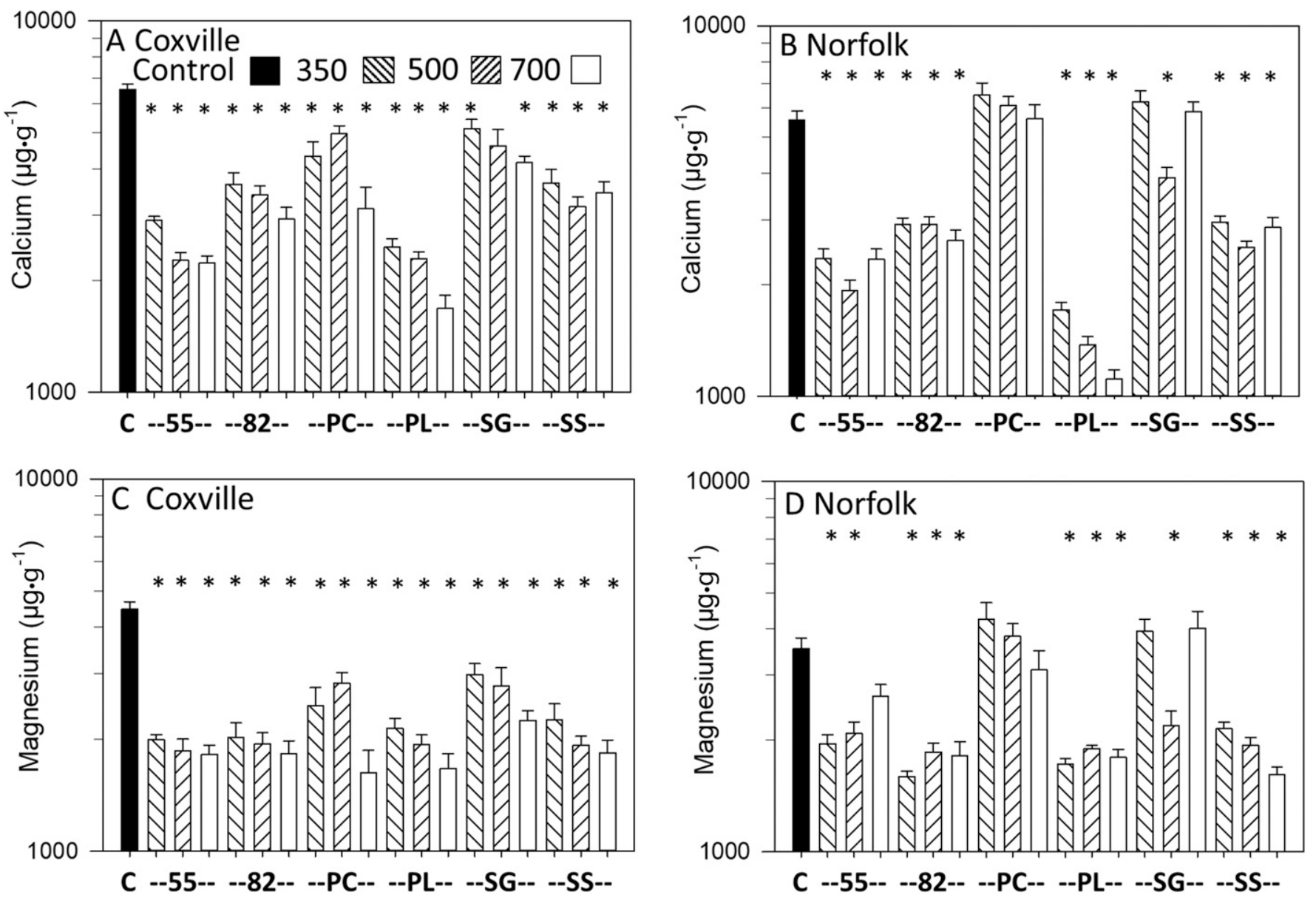

Fig. 1. Effects of biochar on lettuce leaf Ca and $\mathrm{Mg}$ in $\mu \mathrm{g} \cdot \mathrm{g}^{-1}$. Data are for Ca for the Coxville (A) or Norfolk (B) soil, and Mg for the Coxville (C) or Norfolk (D) soil. $\mathrm{C}=$ no biochar control, $\mathrm{PL}=$ poultry litter, $\mathrm{PC}=$ pine chips, $55=50 \% \mathrm{PC}$ and $50 \% \mathrm{PL}, 82=80 \% \mathrm{PC}$ and $20 \% \mathrm{PL}, \mathrm{SS}=$ swine solids, $\mathrm{SG}=\mathrm{switchgrass}$. Temperatures in ${ }^{\circ} \mathrm{C}$ are indicated above the graph. Each bar is based on back-transformed least square mean and upper standard error (see methods) for six pots except for 5 for Coxville PL 500, Norfolk PC 350, Norfolk 82350 and 500, Norfolk PL 500 and 700. An “*” above a bar indicates a significant difference vs. control plants according to Dunnett's test.

Veritas Minerals, Vancouver, BC, Canada) for one sample for each biochar and temperature combination. In brief, samples were digested using Aqua Regia digestion followed by quantifying nutrients using inductively coupled plasma mass spectrometry (ICP-MS) analysis. Each sample was cold leached with HNO, followed by a hot water digestion and cooling. A modified Aqua Regia solution $\left(\mathrm{HCl}, \mathrm{HNO}_{3}\right.$, and $\left.\mathrm{DI} \mathrm{H}_{2} \mathrm{O}\right)$ then was added to each sample, followed by heating in a hot water bath. Samples were brought to volume with dilute $\mathrm{HCl}$, then filtered, and subsequently analyzed using a Perkin Elmer Inc. (Waltham, MA) NexION 300 ICP-MS. The $\mathrm{S}$ and $\mathrm{P}$ concentrations were presented elsewhere (Olszyk et al., 2018), while the concentrations for the other elements are discussed for the first time in this article.

Plants. This study focused on two crops used for direct human consumption, carrot and lettuce. Seeds for each crop plant were planted into soil and soil-plus-biochar mixtures in 10$\mathrm{cm}$ diameter green plastic pots with geotextile cloth lining the bottom of the pot. There were about eight lettuce or five carrot seeds per pot.

Lettuce (Lactuca sativa L. cv. BlackSeeded Simpson) was planted 8 Nov. 2013 and harvested 15 Jan. 2014, and carrot [Daucus carota subsp. sativus (Hoffm.) Schübl. cv. Tendersweet] was planted 13 Nov. 2013 and was harvested 22 Jan. 2014. After seeds were planted, deionized $\mathrm{H}_{2} \mathrm{O}$ was added to the soil with and without biochar at an amount necessary to obtain a soil moisture content of $10 \%(\mathrm{w} / \mathrm{w})$. Soon after initial water addition, lettuce received $0.068 \mathrm{~g} \mathrm{KH}_{2} \mathrm{PO}_{4}$ and $0.076 \mathrm{~g} \mathrm{NH}_{4} \mathrm{NO}_{3}$ per pot, equivalent to $67 \mathrm{~kg} \cdot \mathrm{ha}^{-1} \mathrm{P}, 85 \mathrm{~kg} \cdot \mathrm{ha}^{-1} \mathrm{~K}$ and $112 \mathrm{~kg} \cdot \mathrm{ha}^{-1} \mathrm{~N}$, respectively. Slightly more fertilizer was added to the carrot pots; i.e., $\approx 0.073-0.076$ $\mathrm{g} \mathrm{KH}_{2} \mathrm{PO}_{4}$ and $0.082-0.084 \mathrm{~g} \mathrm{NH}_{4} \mathrm{NO}_{3}$ per pot, equivalent to $\approx 72-74 \mathrm{~kg} \cdot \mathrm{ha}^{-1} \mathrm{P}, 92-94$ $\mathrm{kg} \cdot \mathrm{ha}^{-1} \mathrm{~K}$, and $121-124 \mathrm{~kg} \cdot \mathrm{ha}^{-1} \mathrm{~N}$. The fertilizer was dissolved in reverse-osmosis $(\mathrm{R} / \mathrm{O})$ water with a pipettor delivering the desired amount of $\mathrm{N}, \mathrm{P}$, and $\mathrm{K}$ to each pot. Pots subsequently were watered with $\mathrm{R} / \mathrm{O}$ water whenever the top of the soil was dry to the touch. Plants were thinned to one plant per pot after germination. Plants were grown in a greenhouse under $1000-\mathrm{W}$ high intensity discharge lights with a 16-h light/8-h dark photoperiod. Average daily greenhouse environmental conditions from emergence to harvest were $15.3{ }^{\circ} \mathrm{C}$ (both crops), 195 (car- rot) or 188 (lettuce) $\mu \mathrm{mol} \cdot \mathrm{m}^{-2} \cdot \mathrm{s}^{-1}$ photosynthetically active radiation from 400 to $700 \mathrm{~nm}$ (PAR), and 36\% (carrot) or 39\% (lettuce) relative humidity $(\mathrm{RH})$.

At harvest, lettuce and carrot leaves were removed from the plants and dried at about ambient air temperature (no extra heat) for 29 and $22 \mathrm{~d}$, respectively, before drying at $60^{\circ} \mathrm{C}$. For carrot root systems, pots were randomly assigned to two groups. For group A carrot pots, root systems were immediately washed with $\mathrm{R} / \mathrm{O}$ water to remove soil, followed by separation of young, developing taproot and diffuse roots; drying at $60{ }^{\circ} \mathrm{C}$; and weighing. Group B carrot pots were used for a leachate study of soil water chemistry. Thus, the B pots were placed in plastic bags and put into a cool room at $\approx 4{ }^{\circ} \mathrm{C}$ for $\approx 24$ to $42 \mathrm{~d}$ until leached with Milli-Q water, and the leachate collected. After leaching was complete, all B pots were processed using the same procedures as for group A pots. Data for group A and B root systems were combined for analysis.

Lettuce leaf and carrot taproot samples were ground using a Wiley ${ }^{\circledR}$ mill. Samples were digested using automated block digestors using EPA method 3050B (U.S. EPA, 1996). The digestate was analyzed for total 

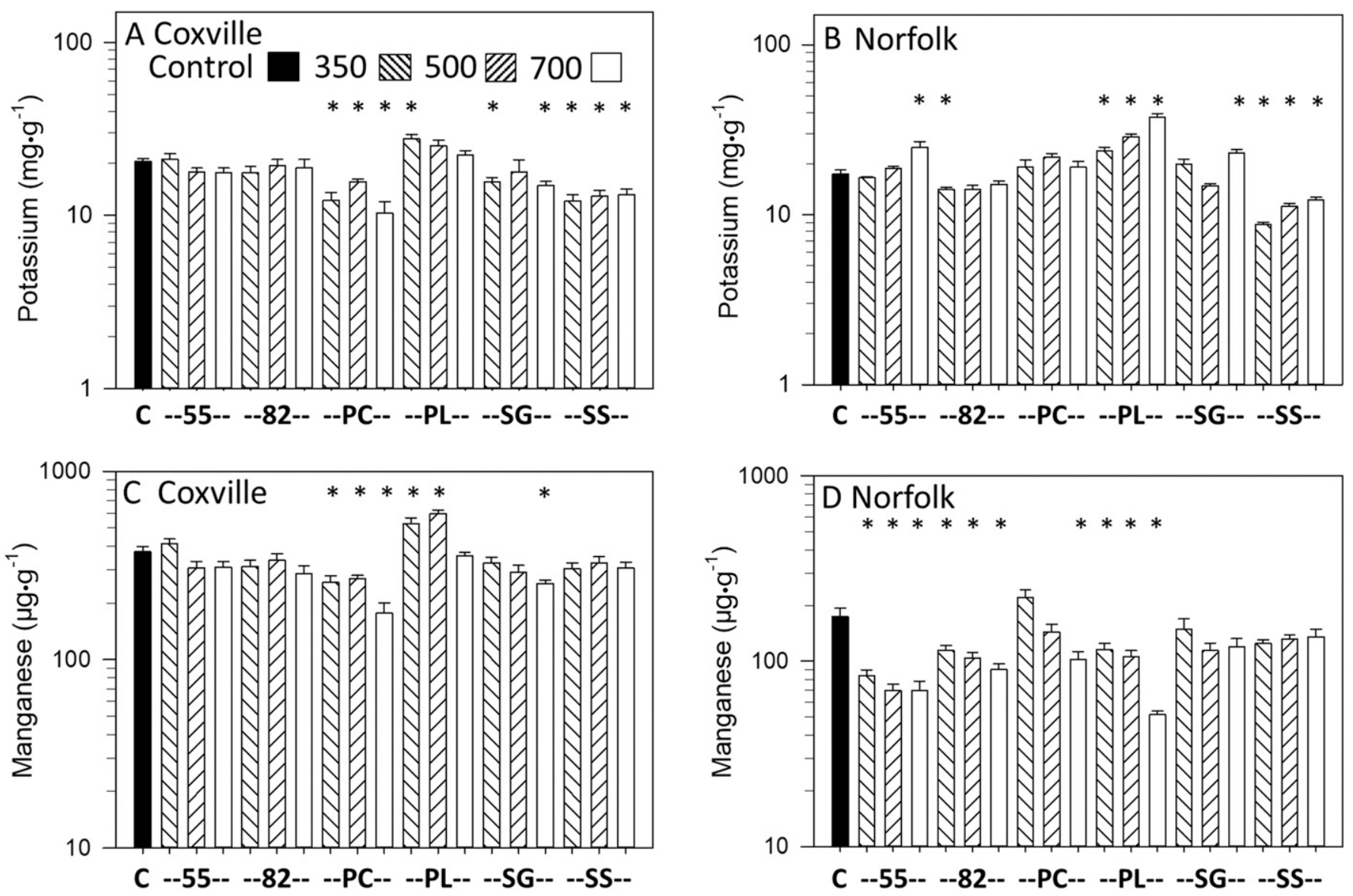

Fig. 2. Effects of biochar on lettuce leaf $\mathrm{K}$ in $\mathrm{mg} \cdot \mathrm{g}^{-1}$ and $\mathrm{Mn}$ in $\mu \mathrm{g} \cdot \mathrm{g}^{-1}$. Data are for $\mathrm{K}$ for the Coxville (A) or Norfolk (B) soil, and Mn for the Coxville (C) or Norfolk (D) soil. $\mathrm{C}=$ no biochar control, $\mathrm{PL}=$ poultry litter, $\mathrm{PC}=$ pine chips, $55=50 \% \mathrm{PC}$ and $50 \% \mathrm{PL}, 82=80 \% \mathrm{PC}$ and $20 \% \mathrm{PL}, \mathrm{SS}=$ swine solids, $\mathrm{SG}=$ switchgrass. Temperatures in ${ }^{\circ} \mathrm{C}$ are indicated above the graph. Each bar is based on back-transformed least square mean and upper standard error (see methods) for six pots except for 5 for Coxville PL 500, Norfolk PC 350, Norfolk 82350 and 500, Norfolk PL 500 and 700 . An “*” above a bar indicates a significant difference vs. control plants according to Dunnett's test.

nutrient concentrations with a Varian VistaPRO ICP-OES (Mulgrave, Victoria, Australia) or a PerkinElmer Optima 8300 ICP-OES (Waltham, MA). The lettuce leaf and carrot taproot nutrient concentrations were expressed on a $\mu \mathrm{g} \cdot \mathrm{g}^{-1}$ basis, except for $\mathrm{mg} \cdot \mathrm{g}^{-1}$ for $\mathrm{K}$.

Experimental design and statistical analysis. For each crop there were 18 biochar treatments (six feedstocks $\times$ three pyrolysis temperatures), plus a no-biochar control; with the treatments and controls repeated for each soil type. There were six replicates per treatment and soil type. The study used a completely randomized design with pots randomly located across a greenhouse bench and rotated to change position at least once during the experiment.

Nutrient data were $\log _{10}$ transformed before statistical analysis, as treatment effects were assumed to be additive on a $\log$ scale. A small value $\left(0.1 \mu \mathrm{g} \cdot \mathrm{g}^{-1}\right.$, or 0.5 $\mu \mathrm{g} \cdot \mathrm{g}^{-1}$ for carrot taproot $\mathrm{Fe}$ ) was added to "0" values before log transformation. Because of heterogeneity of variance, a weighted analysis of variance (ANOVA) was used with weights proportional to the inverse of the variances for the transformed data for each soil and biochar treatment (Welch, 1951).
The PROC MIXED ANOVA procedures in SAS/STAT ${ }^{\circledR}$ software (SAS Institute Inc., Cary, NC) were used to analyze data separately for each crop. The ANOVAs were carried out to compare treatments. The factors were soil and treatment (18 biochar treatments plus control plants) and soil $\times$ treatment interactions. When there was a significant soil $\times$ treatment interaction, a Dunnett's test at $P<0.05$ was used to compare individual treatments to the control plants separately for each soil. The means and standard errors in the figures were based on back-transformations of the least squares means and standard errors from the statistical analysis to provide results with the same nontransformed units as the original data. The back-transformed standard errors used in figures are the average based on upper and lower least square standard errors.

\section{Results}

Biochar nutrients. The manure-based biochars (PL and SS) generally had higher nutrient concentrations (Olszyk et al., 2018, Table 3). The SS biochars had the highest $\mathrm{Cu}, \mathrm{Fe}, \mathrm{Mg}, \mathrm{Mn}, \mathrm{P}$, and $\mathrm{Zn}$. The PL biochars had the highest $\mathrm{K}$, as well as high concentrations of $\mathrm{Mg}, \mathrm{Mn}, \mathrm{P}$, and $\mathrm{Zn}$. Both SS and $\mathrm{PL}$ had high $\mathrm{Ca}$ and $\mathrm{S}$. The other elements were intermediate for SS and PL, and the 55 and 82 mixtures of PL and PC had intermediate concentrations of all nutrients. The cellulosic biochars PC and SG had low concentrations of all nutrients. For the PL and SS biochars, nutrient concentrations usually increased with increasing pyrolysis temperatures. In general, nutrient concentrations varied less consistently with temperature for the mixtures and cellulosic-based biochars.

Lettuce leaf nutrients. Compared with the no-biochar control plants, lettuce leaf $\mathrm{Ca}$ and $\mathrm{Mg}$ concentrations were reduced substantially by nearly all biochars (Fig. 1). For the Coxville soil, the only biochar treatment that did not significantly reduce the nutrient concentration was for $\mathrm{Ca}$ with $\mathrm{SG}$ at $500^{\circ}$ (Fig. 1A), while all biochar treatments caused significant reductions in lettuce leaf $\mathrm{Mg}$ (Fig. 1C). For the Norfolk soil, the cellulosic biochars had less effect than the other biochars on $\mathrm{Ca}$ and $\mathrm{Mg}$ concentrations - with no response to $\mathrm{PC}$ for either nutrient - and with $\mathrm{SG}$ only a reduction in leaf $\mathrm{Ca}$ and $\mathrm{Mg}$ at $500^{\circ}$ (Fig. 1B and D). The 55 biochar at $700^{\circ}$ also 

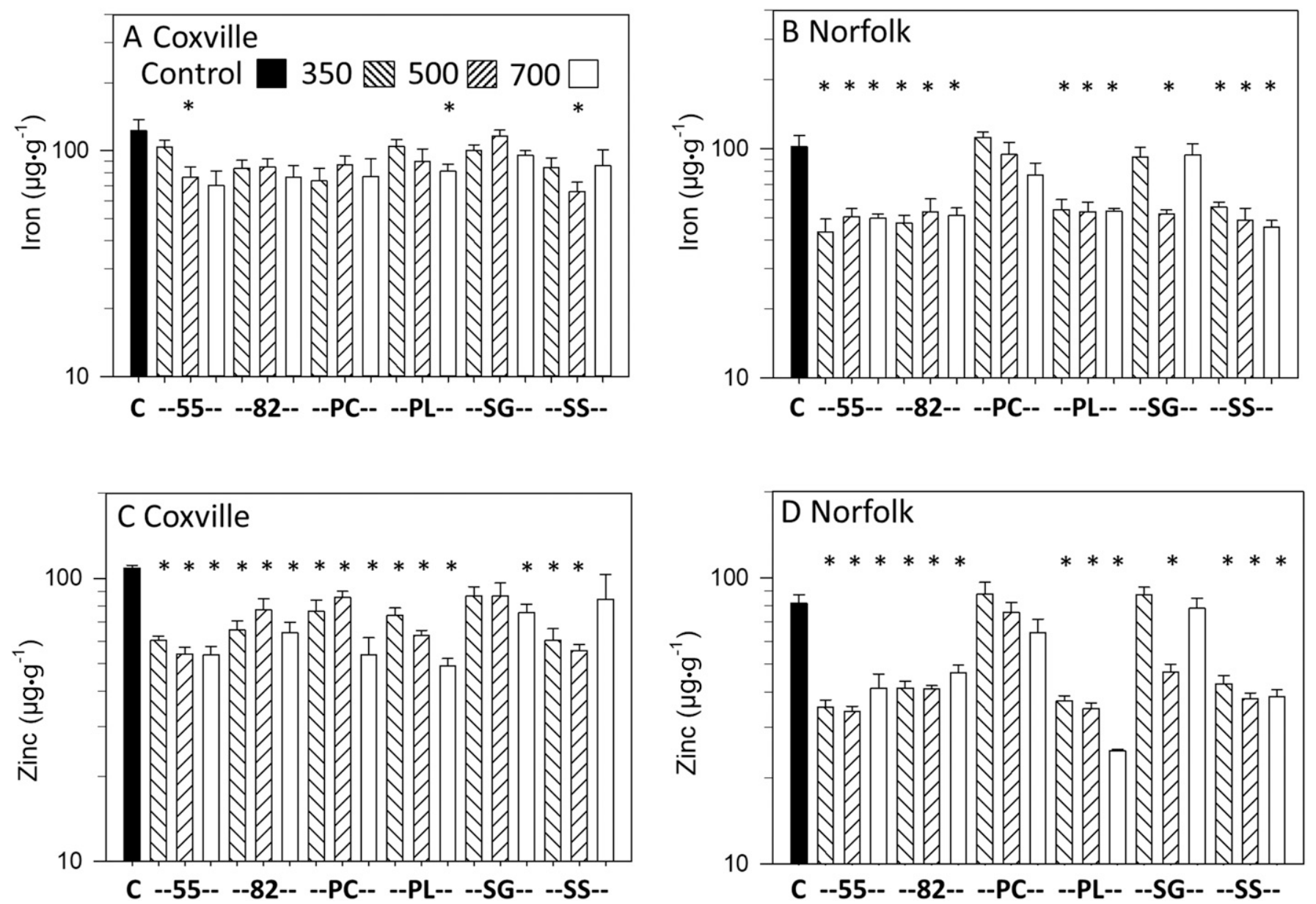

Fig. 3. Effects of biochar on lettuce leaf Fe and Zn in $\mu \mathrm{g} \cdot \mathrm{g}^{-1}$. Data are for Fe for the Coxville (A) or Norfolk (B) soil, and Zn for the Coxville (C) or Norfolk (D) soil. $\mathrm{C}=$ no biochar control, $\mathrm{PL}=$ poultry litter, $\mathrm{PC}=$ pine chips, $55=50 \% \mathrm{PC}$ and $50 \% \mathrm{PL}, 82=80 \% \mathrm{PC}$ and $20 \% \mathrm{PL}, \mathrm{SS}=$ swine solids, $\mathrm{SG}=\mathrm{switchgrass}$. Temperatures in ${ }^{\circ} \mathrm{C}$ are indicated above the graph. Each bar is based on back-transformed least square mean and upper standard error (see methods) for six pots except for 5 for Coxville PL 500, Norfolk PC 350, Norfolk 82350 and 500, Norfolk PL 500 and 700 for both Fe and Mn, and 5 for Coxville SS 700 for Fe. An

“*” above a bar indicates a significant difference vs. control plants according to Dunnett's test.

had no effect on leaf $\mathrm{Mg}$ for the Norfolk soil (Fig. 1D). There were differences in biochar effects on lettuce leaf $\mathrm{Ca}$ and $\mathrm{Mg}$ among pyrolysis temperatures for different biochars, but no consistent pattern in responses for either soil.

In contrast to the general decreases in leaf $\mathrm{Ca}$ and $\mathrm{Mg}$ with many biochar treatments, there were increases as well as decreases in lettuce $\mathrm{K}$ with biochar. Leaf $\mathrm{K}$ decreased for $\mathrm{SS}$ with both soils, $\mathrm{PC}$ for the Coxville soil, SG at 350 and $700{ }^{\circ} \mathrm{C}$ for the Coxville soil, and 82 at $350{ }^{\circ} \mathrm{C}$ for the Norfolk soil (Fig. $2 \mathrm{~A}$ and $\mathrm{B})$. Leaf $\mathrm{K}$ concentrations increased for $\mathrm{PL}$ at $350^{\circ} \mathrm{C}$ for the Coxville soil (Fig. 2A), and for $\mathrm{PL}$ at all temperatures as well as 55 and SG at $700{ }^{\circ} \mathrm{C}$ for the Norfolk soil (Fig. 2B).

In terms of micronutrients, biochar decreased lettuce leaf Mn concentrations with $\mathrm{PC}$ at all temperatures and SG at $700{ }^{\circ} \mathrm{C}$, but increased Mn with PL at 350 and $500^{\circ} \mathrm{C}$ for the Coxville soil (Fig. 2C). Biochar decreased leaf Mn for the Norfolk soil with the 55, 82 and PL biochars at all temperatures, and $\mathrm{PC}$ at $700{ }^{\circ} \mathrm{C}$ (Fig. 2D). Lettuce leaf $\mathrm{Fe}$ concentrations decreased for the Coxville soil only with 55 and $\mathrm{SS}$ at
$500{ }^{\circ} \mathrm{C}$ and $\mathrm{PL}$ at $700{ }^{\circ} \mathrm{C}$, even though there was a trend toward lower $\mathrm{Fe}$ with most other biochar treatments (Fig. 3A). For the Norfolk soil, nearly all biochar feedstocks decreased $\mathrm{Fe}$ concentrations, with the exceptions of $\mathrm{PC}$ at all temperatures and $\mathrm{SG}$ at 350 and $700{ }^{\circ} \mathrm{C}$ (Fig. 3B). Leaf Zn concentrations decreased with PL, SS, 55 and 82 for both soils, PC for the Coxville soil, and $\mathrm{SG}$ at $700{ }^{\circ} \mathrm{C}$ for the Coxville soil; and $\mathrm{SG}$ at $500{ }^{\circ} \mathrm{C}$ for the Norfolk soil (Fig. 3C and $\mathrm{D})$. The reductions in lettuce leaf $\mathrm{Zn}$ followed a pattern like that for $\mathrm{Ca}$ and $\mathrm{Mg}$ for the Coxville soil, and $\mathrm{Ca}, \mathrm{Mg}$, and $\mathrm{Fe}$ for the Norfolk soil.

Carrot taproot nutrients. Biochar effects on developing carrot taproot nutrient concentrations followed a different pattern of response compared with lettuce leaves. Biochar had no effect on taproot $\mathrm{Ca}$ concentrations for the Coxville soil (Fig. 4A), but decreased taproot $\mathrm{Ca}$ with $\mathrm{PL}$ at all temperatures, 55 at 500 and $700{ }^{\circ} \mathrm{C}$, and SS at $500{ }^{\circ} \mathrm{C}$ for the Norfolk soil (Fig. 4B). Taproot $\mathrm{Mg}$ for the Coxville soil, decreased with 55, 82, PC, SG, and SS with biochars produced at $700^{\circ}$; and 55 at $500{ }^{\circ} \mathrm{C}$ (Fig. 4C). For the Norfolk soil, only 55 at $700{ }^{\circ} \mathrm{C}$ and $\mathrm{PL}$ at $500{ }^{\circ} \mathrm{C}$ decreased taproot $\mathrm{Mg}$, while $\mathrm{SS}$ at $350{ }^{\circ} \mathrm{C}$ increased taproot Mg (Fig. 4D).

Taproot $\mathrm{K}$ concentrations increased with the all biochars with the Coxville soil, for at least one temperature (Fig. 5A). The greatest increases in taproot $\mathrm{K}$ were with PL and 55. In contrast, biochar had little effect on taproot $\mathrm{K}$ with the Norfolk soil, except for increasing $\mathrm{K}$ with $\mathrm{Pl}$ at 350 and $700{ }^{\circ} \mathrm{C}$ and decreasing $\mathrm{K}$ with $\mathrm{SS}$ at all temperatures (Fig. 5B).

Biochar increased taproot $\mathrm{Mn}$ with PL at 350 and $500{ }^{\circ} \mathrm{C}$, but decreased $\mathrm{Mn}$ with 82 at $700{ }^{\circ} \mathrm{C}$ for the Coxville soil (Fig. 5C). Biochar generally reduced taproot $\mathrm{Mn}$ for the Norfolk soil, but there was a large amount of variability among replicate plants, and the decreases were significant only with 55 at $700{ }^{\circ} \mathrm{C}$ and $\mathrm{PC}$ at $500{ }^{\circ} \mathrm{C}$ (Fig. 5D).

Biochar decreased taproot $\mathrm{Fe}$ with a few biochars scattered across all feedstocks, except PC with the Coxville soil, with the largest decrease for 82 at $700{ }^{\circ} \mathrm{C}$ (Fig. 6A); while biochar had no effect on taproot $\mathrm{Fe}$ for the Norfolk soil (Fig. 6B). Taproot Zn for the Coxville soil decreased with $55,82, \mathrm{SG}$, and SS at $700{ }^{\circ} \mathrm{C}$ and 55 at $500{ }^{\circ} \mathrm{C}$; while $\mathrm{Zn}$ 

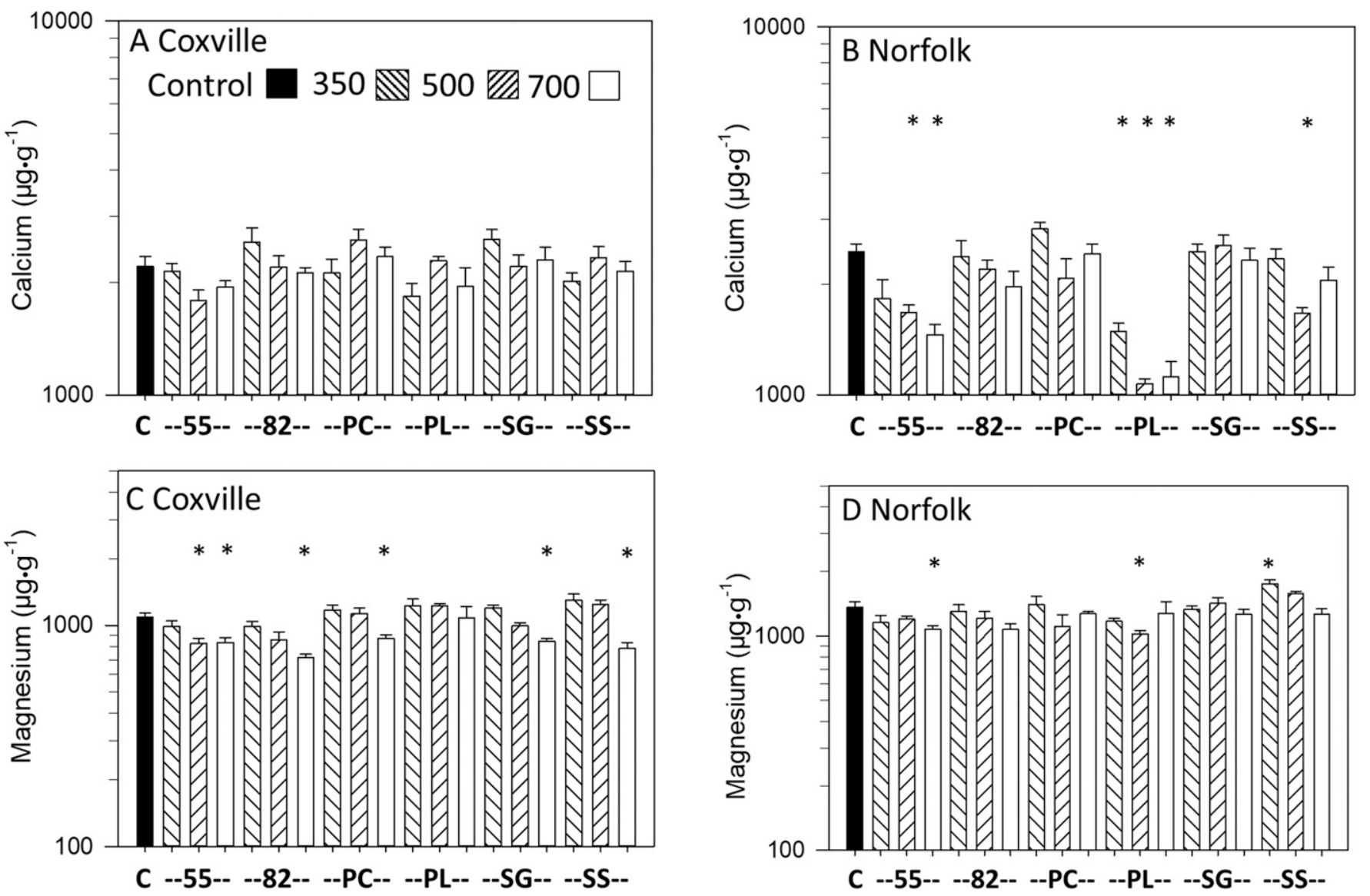

Fig. 4. Effects of biochar on carrot taproot $\mathrm{Ca}$ and $\mathrm{Mg}$ in $\mu \mathrm{g} \cdot \mathrm{g}^{-1}$. Data are for Ca for the Coxville (A) or Norfolk (B) soil, and Mg for the Coxville (C) or Norfolk (D) soil. $\mathrm{C}=$ no biochar control, $\mathrm{PL}=$ poultry litter, $\mathrm{PC}=$ pine chips, $55=50 \% \mathrm{PC}$ and $50 \% \mathrm{PL}, 82=80 \% \mathrm{PC}$ and $20 \% \mathrm{PL}, \mathrm{SS}=$ swine solids, $\mathrm{SG}=$ switchgrass. Temperatures in ${ }^{\circ} \mathrm{C}$ are indicated above the graph. Each bar is based on back-transformed least square mean and upper standard error (see methods) for six pots except for 3 for Coxville PL 500, 4 for Norfolk PL 700, and 5 for Coxville PL 700, Norfolk PC 350, Norfolk 82350 and 500, Norfolk PL 350 and 500 and 55 700. An "*” above a bar indicates a significant difference vs. control plants according to Dunnett's test.

increased with PL and SS at $350^{\circ} \mathrm{C}$ (Fig. 6C). The only biochar effect on $\mathrm{Zn}$ for the Norfolk soil was a decrease with 55 at $700{ }^{\circ} \mathrm{C}$ (Fig. 6D).

\section{Discussion}

Despite the many potential benefits for crop growth due to amending soil with biochar, there may be unexpected consequences if the effects of the biochar on plant nutrients are not carefully considered. Successful plant growth depends on an adequate supply of plant nutrients, with growth rates increasing with increasing nutrient concentrations (McDonald, 1994). There is considerable literature on biochar and nutrients relating to plants (Chan and $\mathrm{Xu}, 2009$; De Luca et al., 2015). Fewer studies relate biochar and plant nutrients to human health. Some of these emphasized an excess of heavy metals in plants with some biochars (Subedi et al., 2017), or use of biochar to reduce heavy metals in plants (Peng et al., 2018). A few studies considered use of biochar and nutrients in plants relative to human health. For example, nutrient increases were due to use of a biochar feedstock with a high nutrient concentration (e.g., macroalgae from wastewater, in Roberts et al., 2015), or an enhanced increase in essential nutrients when biochar was applied with a concentrated source of nutrients such as Fe fertilizer (Ramzani et al., 2016a, 2016b) or biosolids (Gartler et al., 2013). Ramzani et al. (2017) applied only biochar and found increases in essential nutrients, but the biochar had been acidified with sulfur. When biochar by itself was applied to soil, essential nutrients were reduced in wheat grains (Hartley et al., 2016).

In our study, some biochar treatments enhanced $\mathrm{K}$ concentrations, i.e., in lettuce with PL for both soils with at least one temperature (Fig. 2A and B); possibly this result was due to an extra fertilization effect of the biochar (in addition to the added fertilizer), as soil $\mathrm{K}$ concentrations were low in this study. This increase in $\mathrm{K}$ with biochar was like the results in other studies (Biederman and Harpole, 2013). In a similar study with lettuce and PL biochar, shoot K also increased (Gunes et al., 2014). Using charcoal instead of biochar, Deenik et al. (2010) observed a similar increase in leaf K concentration for lettuce for plants receiving high levels of charcoal $(10 \%$ and $20 \%$ by weight) when no fertilizer was used. Deenik et al. (2010) observed an increase in lettuce leaf $\mathrm{K}$ uptake with $10 \%$ charcoal, but a decrease in leaf K uptake with $20 \%$ charcoal.
Deenik et al. (2010) also noted increases in lettuce leaf $\mathrm{Ca}, \mathrm{Mg}, \mathrm{Fe}, \mathrm{Mn}$, and $\mathrm{Zn}$; but decreases in leaf $\mathrm{K} \mathrm{Ca}, \mathrm{Mg}$ and $\mathrm{Zn}$ uptake, primarily with the highest charcoal rate. Sorrenti et al. (2016) reported an increase in leaf $\mathrm{K}$ when tree fruit wood biochar was applied to kiwifruit vines. Potassium also increased in carrot taproots for many biochars with the Coxville soil, and PL at 350 and $700{ }^{\circ} \mathrm{C}$ with the Norfolk soil (Fig. 5A and $B)$. If these increases persisted in the harvestable crops, their nutritive value in terms of lettuce leaf or carrot taproot $\mathrm{K}$ would further increase beyond the healthy levels already present in the tissues (Rudrappa, 2019).

In contrast, the decreases in leaf nutrient concentrations we observed with many of the biochar treatments across all elements and both crops could reduce crop quality for direct human consumption. For example, the reported data suggest that reductions with some biochars, for example, $\mathrm{Ca}, \mathrm{Fe}$, and $\mathrm{Mg}$ in lettuce (Figs. 1A-D and $3 \mathrm{~A}$ and $\mathrm{B}$ ), or $\mathrm{Ca}$ and $\mathrm{Mn}$ in carrot taproots (Figs. 4B and 5C and D) could adversely affect the nutritional values of these crops, as they have healthy amounts of these nutrients (Rudrappa, 2019). In a previous study with lettuce and PL biochar alone, Gunes et al. (2014) also reported decreases in shoot $\mathrm{Mn}$ and possibly $\mathrm{Fe}$ 

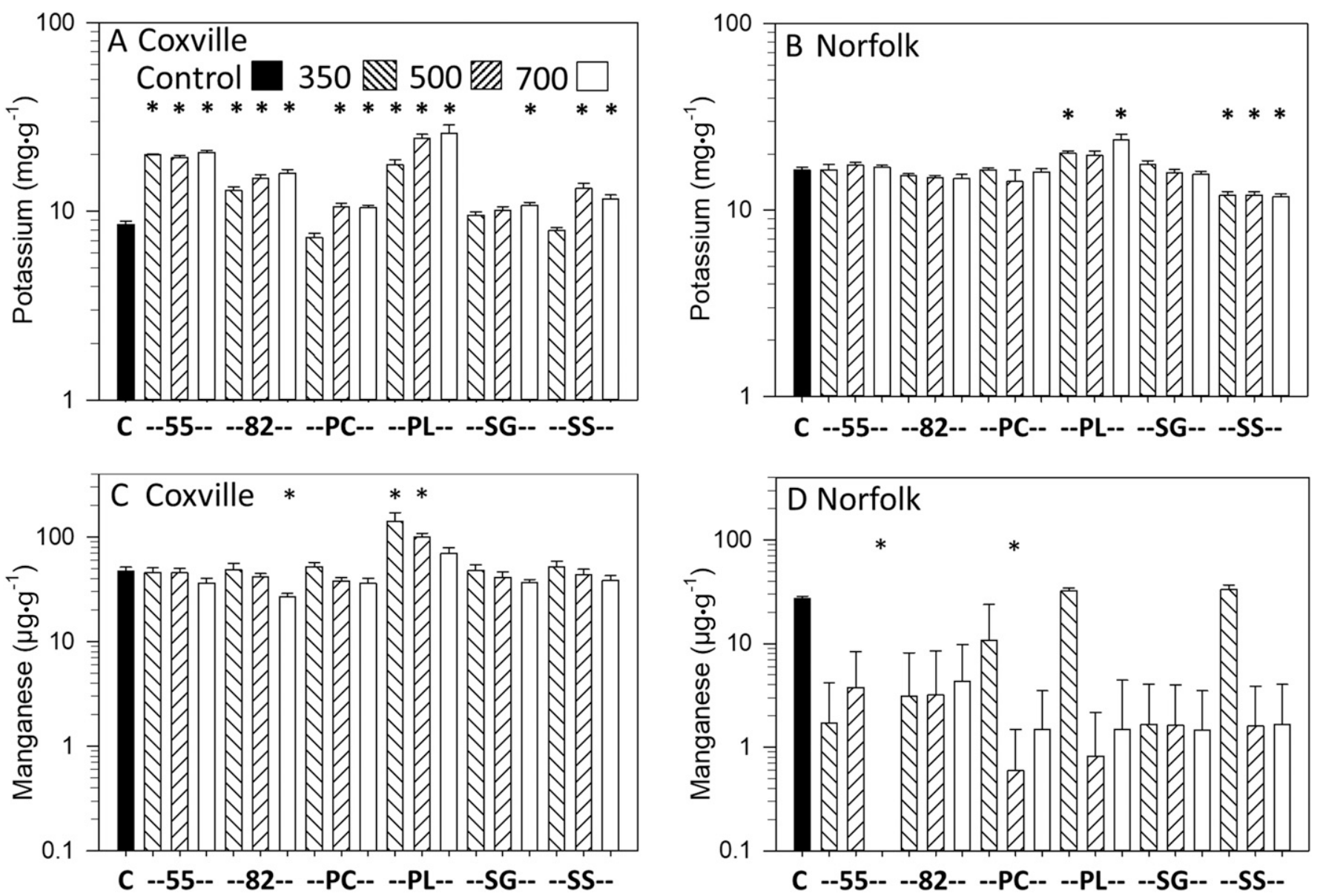

Fig. 5. Effects of biochar on carrot taproot $\mathrm{K}$ in $\mathrm{mg} \cdot \mathrm{g}^{-1}$ and $\mathrm{Mn}$ in $\mu \mathrm{g} \cdot \mathrm{g}^{-1}$. Data are for Ca for the Coxville (A) or Norfolk (B) soil, and Mn for the Coxville (C) or Norfolk $(\mathrm{D})$ soil. $\mathrm{C}=$ no biochar control, $\mathrm{PL}=$ poultry litter, $\mathrm{PC}=$ pine chips, $55=50 \% \mathrm{PC}$ and $50 \% \mathrm{PL}, 82=80 \% \mathrm{PC}$ and $20 \% \mathrm{PL}, \mathrm{SS}=$ swine solids, $\mathrm{SG}=$ switchgrass. Temperatures in ${ }^{\circ} \mathrm{C}$ are indicated above the graph. Each bar is based on back-transformed least square mean and upper standard error (see methods) for six pots except for 3 for Coxville PL 500, 4 for Norfolk PL 700, and 5 for Coxville PL 700, Norfolk PC 350, Norfolk 82 350 and 500, Norfolk PL 350 and 500 and 55 700. An “*” above a bar indicates a significant difference vs. control plants according to Dunnett's test.

concentrations, but no changes in shoot $\mathrm{Ca}$ or $\mathrm{Mg}$ concentrations.

Soil $\mathrm{pH}$ would be a key factor in availability of the nutrients, especially for the metals evaluated in this study (Barber, 1984). In a previous seed germination study, we showed that the PL, 55, SS, and to a lesser extent $82, \mathrm{SG}$, and $\mathrm{PC}$ biochars increased $\mathrm{pH}$ vs. the controls across plant species depending to some extent on soil type, with the largest increase to about $\mathrm{pH} 6.7$ for PL pyrolyzed at $700{ }^{\circ} \mathrm{C}$ vs. 5.6 for the controls across the Coxville and Norfolk soils (Olszyk et al., 2018). A similar increase in soil $\mathrm{pH}$ was seen with PL biochar in research with a low pH mine soil (Novak et al., 2019). These increases in soil $\mathrm{pH}$ would lower the solubility of $\mathrm{Fe}, \mathrm{Mn}$, and $\mathrm{Zn}$, thus decreasing their concentrations in solution (Barber, 1984). This explanation could, at least in part, explain the decreases in those nutrients in our plants; especially with the manure-based biochars for lettuce leaves, and to a lesser extent for carrot taproots.

In general, increases in soil $\mathrm{pH}$, especially with the PL biochar (Olszyk et al., 2018), should have made $\mathrm{Ca}$ and $\mathrm{Mg}$ (to $\mathrm{pH}$ 6.5) more available (Barber, 1984; USDA, 2014) and increased lettuce leaf concentrations, instead of the widespread decreases that we observed. Thus, decreases in $\mathrm{Ca}$ and $\mathrm{Mg}$ were likely associated with other factors that affect the availability of nutrients from the soil (Barber, 1984). For example, an increase in $\mathrm{pH}$ leads to lower concentrations of plantavailable $\mathrm{P}$ due to binding with $\mathrm{Ca}$ in the biochar (Novak et al., 2019), which could lead to lower leaf $\mathrm{Ca}$. Above $\mathrm{pH} 6.5$, as occurred for the Norfolk soil especially with the PL and 55 biochars in a seed germination study (Olszyk et al., 2018), exchangeable Mg could decrease under some conditions (Barber, 1984), and could contribute to decreases in leaf $\mathrm{Mg}$ concentrations.

It was possible that the general lower leaf $\mathrm{Ca}$ and $\mathrm{Mg}$ concentrations we found in lettuce could be due to excess $\mathrm{Zn}$ in the biochars. O'Toole et al. (2013) suggested that the $\mathrm{Zn}$ in galvanized metal containers used during their studies likely increased biochar $\mathrm{Zn}$, which reduced plant $\mathrm{Ca}$ and $\mathrm{Mg}$. However, we used ceramic bowls to make biochar, and, thus we did not have a metal container factor. Instead, we found high $\mathrm{Zn}$ concentrations $(\approx 5000$ to 6800 ppm) in our SS biochar (Table 3) likely due to the addition of $\mathrm{Zn}$ to swine feed as a supplement (Sistani and Novak, 2006). The
Zn concentration also was elevated in the PL biochar in our study (Table 3); however, neither the SS nor PL biochar increased Zn in lettuce leaves (Fig. 3C and D). For carrot taproots, the $\mathrm{Zn}$ concentration increased only with PL and SS pyrolyzed at $350{ }^{\circ} \mathrm{C}$ with the Coxville soil (Fig. 6C), while SS decreased the taproot $\mathrm{Zn}$ concentration at the highest pyrolysis temperature with the Coxville soil.

Instead of increases, we primarily found reductions in $\mathrm{Zn}$ concentrations, especially for lettuce leaves and most often with manure-based biochars (Fig. 3C and D). In a previous study with lettuce and PL biochar, Gunes et al. (2014) found a reduction in shoot $\mathrm{Zn}$. Kim et al. (2015) also reported a decrease in lettuce leaf $\mathrm{Zn}$ concentration with biochar application, but only tested a cellulosic rice hull biochar. Decreases in $\mathrm{Zn}$ concentrations in Lolium perenne L. shoots were found with increasing levels of $80 \%$ coniferous and $20 \%$ hardwood chips biochar and two soils (Rees et al., 2015). Rees et al. (2015) also reported that the $\mathrm{Zn}$ concentration decreased in shoots of the $\mathrm{Cd}$ - and $\mathrm{Zn}$ - hyperaccumulator plant Noccaea caerulescens (J. Presl \& C. Presl) F.K. Mey. when grown on the lower $\mathrm{pH}$ (5.89) soil, while $\mathrm{Zn}$ did not change with biochar on 

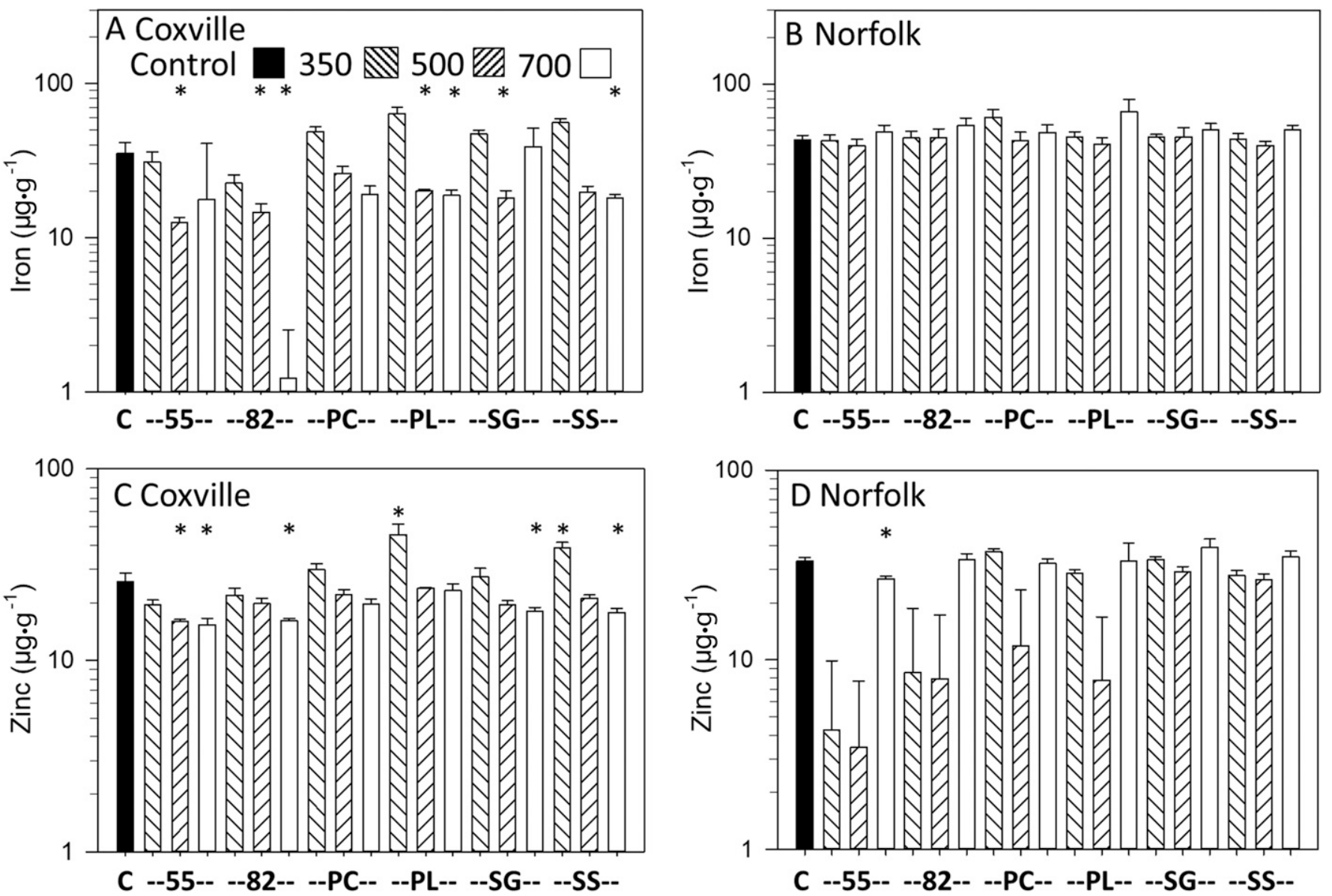

Fig. 6. Effects of biochar on carrot taproot Fe and Zn in $\mu \mathrm{g} \cdot \mathrm{g}^{-1}$. Data are for Fe for the Coxville (A) or Norfolk (B) soil, and Zn for the Coxville (C) or Norfolk (D) soil. $\mathrm{C}=$ no biochar control, $\mathrm{PL}=$ poultry litter, $\mathrm{PC}=$ pine chips, $55=50 \% \mathrm{PC}$ and $50 \% \mathrm{PL}, 82=80 \% \mathrm{PC}$ and $20 \% \mathrm{PL}$, SS $=$ swine solids, $\mathrm{SG}=$ switchgrass. Temperatures in ${ }^{\circ} \mathrm{C}$ are indicated above the graph. Each bar is based on back-transformed least square mean and upper standard error (see methods) for six pots except for 3 for Coxville PL 500, 4 for Norfolk PL 700, and 5 for Coxville PL 700, Norfolk PC 350, Norfolk 82350 and 500, Norfolk PL 350 and 500 and 55 700. An "*" above a bar indicates a significant difference vs. control plants according to Dunnett's test.

the higher $\mathrm{pH}$ (8.07) soil. Both Kim et al. (2015) and Rees et al. (2015) used high heavy metal concentration soils from near smelters, while we used uncontaminated soils.

In both Kim et al. (2015) and Rees et al. (2015), the decrease in leaf $\mathrm{Zn}$ was likely related to an increase in soil $\mathrm{pH}$ with addition of biochar, especially for a more acidic soil. This suggests that an increase in $\mathrm{pH}$ with addition of biochar can be related to reduced plant $\mathrm{Zn}$ concentration. As indicated earlier, in a seed germination study we found a general increased soil $\mathrm{pH}$ with the same biochars, biochar level, and soils as in this study, with the greatest increase with PL pyrolyzed at $700{ }^{\circ} \mathrm{C}$ (Olszyk et al., 2018).

Feedstock type is also a likely factor in the crop response to biochar. In our study, the cellulosic PC biochar had no statistically significant effects comparted to control plants for carrot tap root $\mathrm{Zn}$ for both soils (Fig. 6C and D) or lettuce shoot $\mathrm{Zn}$ with the Norfolk soil (Fig. 3D). This was similar to the results of Gartler et al. (2013), who found no effect on lettuce $\mathrm{Zn}$ with PC biochar; and Chen et al. (2018), who indicated little overall effect of wood (cellulosic) biochar on plant $\mathrm{Zn}$ concentrations in their metaanalysis. However, there was a reduction in lettuce $\mathrm{Zn}$ concentration with $\mathrm{PC}$ for the Coxville soil in our study. We saw a decrease in lettuce leaf $\mathrm{Zn}$ primarily with the manurebased biochars, whereas Chen et al. (2018) reported little change in plant $\mathrm{Zn}$ with manure biochars.

We saw a reduction in $\mathrm{Fe}$ concentrations in lettuce leaves (both soils, Fig. 3A and B) and carrot taproots (Coxville soil, Fig. 6A), primarily with manure-based biochars. Similarly, with fruit tree wood trimming biochar, Sorrenti et al. (2016, p. 16) found that biochar alone reduced kiwifruit plant Fe uptake. The authors hypothesized that "....in potted conditions $\mathrm{Fe}$ in soil solution was attracted and retained by biochar...thereby limiting its availability...."

There was no clear difference between the two soil types in terms of response of nutrients to biochar in our study. For lettuce leaf and other carrot taproot nutrients, either Coxville or Norfolk had a larger decrease or increase concentration, or there was essentially no difference in response between soils across biochars. While, in general, more coarse or medium texture soils have been shown a greater increase in crop productivity with biochar addition than fine texture soils (Jeffery et al., 2011), there is no clear-cut picture of the relationship between soil char- acteristics, biochar, and concentrations of nutrients in plant tissues. Based on their meta-analysis, Chen et al. (2018) reported a larger decrease in plant $\mathrm{Zn}$ concentrations with biochar applications for a fine soil than with coarse or medium texture soils. However, we saw little difference in lettuce leaf and a highly variable difference in carrot taproot $\mathrm{Zn}$ between the finer texture Coxville and coarser texture Norfolk soil. In the reported study, the largest differences between soils were for carrot, where there was a large increase in taproot $\mathrm{K}$ for many biochars with the finer Coxville soil, but little effect on taproot $\mathrm{K}$ for most biochars with the sandier Norfolk soilexcept for the small increase in $\mathrm{K}$ with PL and decreases with SS (Fig. 5A and B). Similarly, Gaskin et al. (2010) found no effect of pine chip biochar on maize leaf $\mathrm{K}$ growing on a sandy loam Ultisol. However, Gaskin et al. (2010) also reported that a peanut hull biochar increased maize leaf $\mathrm{K}$ on the sandy soil, but primarily in one of two years. We found a reduction in lettuce leaf $\mathrm{Ca}$ and $\mathrm{Mg}$ with the sandier Norfolk soil in addition to the finer Coxville soil, and Syuhada et al. (2016) found a reduction in maize leaf $\mathrm{Ca}$ and $\mathrm{Mg}$ concentrations when biochar was added to a fertilized sandy Pozol. 
Finally, changes in nutrients could also occur due to the overall impact of biochar on the crop growth; i.e., if there is an increase in crop growth leaf, concentrations could decrease due to growth dilution, as suggested by Syuhada et al. (2016). However, further discussion of mechanisms by which biochar results in changes in soil quality and, hence, concentrations of leaf or taproot nutrients, are beyond the scope of this article and will be discussed in future work.

Thus, there is a critical need to produce food with the quality and quantity of nutrients that promote human health (Martin et al., 2011), which may be impacted by biochar amendments to soils. While biochar can have positive effects on the amount of a crop available by increasing yields (Jeffery et al., 2011), especially for tropical soils (Jeffery et al., 2017), the potential role of biochar in affecting the nutrient quality should be further evaluated to optimize its desirable traits and minimize any undesirable characteristics such as absorbing plant nutrients (Kavitha et al., 2018). In addition to evaluating factors such as feedstocks, pyrolysis temperature, and particle size when "designing" a biochar for a specific application (Novak and Busscher, 2012; Novak et al., 2014), researchers should also consider potential impacts on plant nutrients important for human health. The goal should be to produce a biochar that contains inorganic nutrients that can serve as a fertilizer to biofortify crops with essential nutrients (White and Brown, 2010), while avoiding any reductions in these nutrients that would reduce their food value.

\section{Conclusions}

Biochar amendments to soil could increase or decrease concentrations of essential elements in edible parts of plants, potentially affecting human health. In this study, some biochars increased $\mathrm{K}$ concentrations in both lettuce leaves and carrot taproots, especially the high-K concentration PL biochar. In contrast, a number of biochars primarily decreased $\mathrm{Ca}, \mathrm{Fe}, \mathrm{Mg}, \mathrm{Mn}$, and $\mathrm{Zn}$ concentrations in lettuce leaves; and to a lesser extent, carrot taproots. These decreases occurred despite higher concentrations of these nutrients in the biochar, such as poultry litter, compared with the soil; and these may be related to effects of biochar on soil properties such as $\mathrm{pH}$. Thus, while biochar is a potent component in the array of tools scientists possess to enhance crop productivity, unintended consequences (especially in terms of reducing nutrient concentrations in crops) should be carefully considered when designing biochar field amendments.

\section{Literature Cited}

Agegnehu, G., A.M. Bass, P.N. Nelson, and M.I. Bird. 2016. Benefits of biochar, compost and biocharcompost for soil quality, maize yield and greenhouse gas emissions in a tropical agricultural soil. Sci. Total Environ. 543:295-306.

Barber, S.A. 1984. Soil nutrient bioavailability. A mechanistic approach. Wiley, New York.
Biederman, L.A. and W.S. Harpole. 2013. Biochar and its effects on plant productivity and nutrient cycling: a meta-analysis. Glob. Change Biol. Bioenergy 5:202-214.

Bjarnadottir, A. 2019. Carrots 101: Nutrition facts and health benefits. 21 Nov. 2019. <https:// www.healthline.com/nutrition/foods/carrots $>$.

Blok, C., C. Van der Salm, J. Hofland-Zijlstra, M. Streminska, B. Eveleens, I. Regelink, L. Fryda, and R. Visser. 2017. Biochar for horticultural rooting media improvement: Evaluation of biochar from gasification and slow pyrolysis. Agronomy (Basel) 7:6.

Brady, N.C. 1974. The nature and properties of soils. 8th ed. Macmillan, New York.

Broadley, M.R. and P.J. White. 2010. Eats roots and leaves. Can edible horticultural crops address dietary calcium, magnesium and potassium deficiencies? Proc. Nutr. Soc. 69:601612.

Butnan, S., J. Deenik, B. Toomsan, M.J. Antal, and P. Vityakon. 2015. Biochar characteristics and application rates affecting crop growth and properties of soils contrasting in texture and minerology. Geoderma $237-$ 238:105-116.

Cantrell, K.B., P.G. Hunt, M. Uchimiya, J.M Novak, and K.S. Ro. 2012. Impact of pyrolysis temperature and manure source on physiochemical characteristics of biochar. Bioresour. Technol. 107:419-428.

Chan, K.Y., L. van Zwieten, I. Meszaros, A. Downie, and S. Joseph. 2008. Using poultry litter biochars as soil amendments. Aust. J. Soil Res. 46:437-444.

Chan, K.Y. and Z.H. Xu. 2009. Biochar: Nutrient Properties and Their Enhancement, p. 67-84. In: J. Lehman and S. Joseph (eds.). Biochar for environmental management: Science and technology. Earthscan, London, UK.

Chen, D., X. Liu, R. Bian, K. Cheng, X. Zhang, J. Zheng, S. Joseph, D. Crowley, G. Pan, and L. Li. 2018. Effects of biochar on availability and plant uptake of heavy metals - A meta-analysis. J. Environ. Manage. 222:76-85.

Clemson University. 2019. Clemson Regulatory Services. Agricultural Service Laboratory. 29 Oct. 2019. <https://www.clemson.edu/public/regulatory/ ag-srvc-lab/soil-testing/soil-lab-methods/sampleextraction.html $>$.

da Silva Dias, J.C. 2014. Nutritional and health benefits of carrots and their seed extracts. Food Nutr. Sci. 5:2147-2156.

Deenik, J.L., T. McClellan, G. Uehara, M.J. Jr. Antal, and S. Campbell. 2010. Charcoal volatile matter content influences plant growth and soil nitrogen transformations. Soil Sci. Soc. Amer. J. 74:1259-1270.

DeLuca, T.H., M.J. Gundale, M.D. MacKenzie, and D.L. Jones. 2015. Biochar effects on soil nutrient transformations, p. 421-454. In: J. Lehman and S. Joseph (eds.). Biochar for environmental management: Science and technology. 2nd ed. Earthscan, London, UK.

Ding, Y., Y. Liu, S. Liu, Z. Li, X. Tan, X. Huang, G. Zeng, L. Zhou, and B. Zheng. 2016. Biochar to improve soil fertility. A review. Agron. Sustain. Dev. 36:36, doi: 10.1007/s13593-016-0372-z.

Doran, J.W., M. Sarrantonio, and M.A. Liebig. 1996. Soil health and sustainability. Adv. Agron. 56:1-54.

Dunlop, S.J., M.C. Arbestain, P.A. Bishop, and J.J. Wargent. 2015. Closing the loop: use of biochar produced from tomato crop green waste as a substrate for soilless, hydroponic tomato production. HortScience 50:1572-1581.

Gartler, J., B. Robinson, K. Burton, and L. Clucas. 2013. Carbonaceous soil amendments to bio- fortify crops with zinc. Sci. Total Environ. 465:308-313.

Gaskin, J.W., R.A. Speir, K. Harris, K.C. Das, R.D. Lee, L.A. Morris, and D.S. Fisher. 2010. Effect of peanut hull and pine chip biochar on soil nutrients, corn nutrient status, and yield. Agron. J. 102:623-633.

Gunes, A., A. Inal, M.B. Taskin, O. Sahin, E.C. Kaya, and A. Atakol. 2014. Effect of phosphorusenriched biochar and poultry manure on growth and mineral composition of lettuce (Lactuca sativa L. cv.) grown in alkaline soil. Soil Use Manage. 30:182-188.

Hartley, W., P. Riby, and J. Waterson. 2016 Effects of three different biochars on aggregate stability, organic carbon mobility and micronutrient bioavailability. J. Environ. Manage. 181:770-778.

Ippolito, J.A., K.A. Spokas, J.M. Novak, R.D. Lentz, and K.B. Cantrell. 2015. Biochar elemental composition and factors influencing nutrient retention, p. 139-163. In: J. Lehman and S. Joseph (eds.). Biochar for environmental management: Science and technology. 2nd ed. Earthscan, London, UK.

Jeffery, S., D. Abalos, K.A. Spokas, and F.G.A. Verheijen. 2015. Biochar effects on crop yield, p. 301-325. In: J. Lehman and S. Joseph (eds.). Biochar for environmental management: Science and technology. 2nd ed. Earthscan, London, UK.

Jeffery, S., F.G.A. Verheijen, M. van der Velde, and A.C. Bastos. 2011. A quantitative review of the effects of biochar application to soils on crop productivity using meta-analysis. Agr. Ecosyst. Environ. 144:175-187.

Jeffery, S., D. Abalos, M. Prodana, A.C. Bastos, J.W. van Groenigen, B.A. Hungate, and F. Verheijen. 2017. Biochar boosts tropical but not temperate crop yields. Environ. Res. Lett. 12:053001.

Joseph, S. 2009. Socio-economic Assessment and Implementation of Small-scale Biochar Projects, p. 359-373. In: J. Lehman and S. Joseph (eds.). Biochar for environmental management: Science and technology. Earthscan, London, UK.

Kavitha, B., P.V.L. Reddy, B. Kim, S.S. Lee, S.K. Pandey, and K.-H. Kim. 2018. Benefits and limitations of biochar amendment in agricultural soils: A review. J. Environ. Manage. 227:146-154.

Kim, H.-S., K.-R. Kim, H.-J. Kim, J.-H. Yoon, J.E. Yang, Y.S. Ok, G. Owens, and K.-H. Kim. 2015. Effect of biochar on heavy metal immobilization and uptake by lettuce (Lactuca sativa $\mathrm{L}$.) in agricultural soil. Environ. Earth Sci. 74:12491259.

KIS Organics 2019. 21 Nov. 2019. https://www. kisorganics.com/products/kis-organics-biocharsoil-mix.

Lehmann, J. and S. Joseph. 2015. Biochar for environmental management: an introduction, p. 1-13. In: J. Lehman and S. Joseph (eds.). Biochar for environmental management: Science and technology. 2nd ed. Routledge, Taylor and Francis, New York.

Martin, C., E. Butelli, K. Petroni, and C. Tonelli. 2011. How can research on plants contribute to promoting human health? Plant Cell 23:1685-1689.

Masud, M.M., L. Jiu-Ju, and X. Ren-Kou. 2014. Use of alkaline slag and crop residue to promote base saturation and reduce acidity of an acidic ultisol. Pedosphere 24:791-798.

McDonald, A.J.S. 1994. Nutrient supply and plant growth, p. 47-57. In: P.J. Lumsden, J.R. Nicholas, and W.J. Davies (eds.). Physiology, growth and development of plants in culture. Springer 
Science+Business Media, B.V., Dordrecht, The Netherlands.

McGrath, J.M., J. Spargo, and C.J. Penn. 2014. Soil fertility and plant nutrition, p. 166-184. In: N.K. Van Alfen (ed.). Encyclopedia of Agriculture and Food Systems, vol. 5. Elsevier, San Diego, CA.

Moreno-Jiménez, E., J.M. Fernández, M. Puschenreiter, P.N. Williams, and C. Plaza. 2016. Availability and transfer to grain of $\mathrm{As}, \mathrm{Cd}, \mathrm{Cu}, \mathrm{Ni}, \mathrm{Pb}$ and $\mathrm{Zn}$ in a barley agri-system: Impact of biochar, organic and mineral fertilizers. Agr. Ecosyst. Environ. 219:171178.

Noumedem, J.A.K., D.E. Djeussi, L. Hritcu, M. Mihasan, and V. Kuete. 2017. Lactuca sativa, p. 437-449. In: V. Kuete (ed.). Medicinal spices and vegetables from Africa. 1st ed. Academic Press, London, UK.

Novak, J.M. and W.J. Busscher. 2012. Selection and use of designer biochars to improve characteristics of southeastern USA coastal plain degraded soils, p. 69-96. In: J.W. Lee (ed.). Advance biofuels and bioproducts. Vol. 1. Springer Science. New York.

Novak, J.M., K.B. Cantrell, and D.W. Watts. 2013. Compositional and thermal evaluations of lignocellulosic and poultry litter chars via high and low temperature pyrolysis. BioEnergy Res. 6:114-130.

Novak, J.M., K.B. Cantrell, D.W. Watts, W.J. Busscher, and M.G. Johnson. 2014. Designing relevant biochars as soil amendments using lignocellulosic-based and manure-based feedstocks. J. Soils Sediments 14:330-343.

Novak, J.M., G.C. Sigua, K.A. Spokas, W.J. Busscher, K.B. Cantrell, D.W. Watts, B. Glaz, and P.G. Hunt. 2015. Plant macro- and micronutrient dynamics in a biochar-amended wetland muck. Water Air Soil Pollut. 226:2228.

Novak, J.M., J.A. Ippolito, D.W. Watts, G.C. Sigua, T.F. Ducey, and M.G. Johnson. 2019. Biochar compost blends facilitate switchgrass growth in mine soils by reducing $\mathrm{Cu}$ and $\mathrm{Zn}$ bioavailability. Biochar 1:97-114.

Olsen, S.R. and L.E. Sommers. 1982. Phosphorus, p. 403-430. In: A. L. Page, R.H. Miller, and D.R. Keeney (eds.). Methods of soil analysis. Part 2, Chemical and microbiological properties, 2nd ed. America Society of Agronomy, Inc., Soil Science Society of America, Inc., Madison, WI.

Olszyk, D.M., T. Shiroyama, J.M. Novak, and M.G. Johnson. 2018. A rapid-test for screening biochar effects on seed germination. Commun. Soil Sci. Plant Anal. 49:2025-2041.

O’Toole, A., K. Knoth de Zarruk, M. Steffens, and D.P. Rasse. 2013. Characterization, stability, and plant effects of kiln-produced wheat straw biochar. J. Environ. Qual. 42:429-436.

Peng, X., Y. Deng, Y. Peng, and K. Yue. 2018. Effects of biochar addition on toxic element concentrations in plants: A meta-analysis. Sci. Total Environ. 616-617:970-977.

Pleasant, B. 2009. Making biochar to improve soil. 21 Nov. 2019. <https://www.motherearthnews.com organic-gardening/making-biochar-improvesoil-zmaz09fmzraw $>$.

Prapagdee, S., S. Piyatiratitivorakul, A. Petsom, and N. Tawinteung. 2014. Application of biochar for enhancing cadmium and zinc phytostabilization in Vigna radiata L. cultivation. Water Air Soil Pollut. 225:2233.

Ramzani, P.M.A., M. Khalid, M. Naveed, R. Ahmad, and M. Shahid. 2016a. Integrating the organic amendment with iron fertilization for improving productivity and Fe biofortification in rice under acidified calcareous soil. Pak. J. Agr. Sci. 53:407-417.

Ramzani, P.M.A., M. Khalid, M. Naveed, R. Ahmad, and M. Shahid. 2016b. Iron biofortification of wheat grains through integrated use of organic and chemical fertilizers in $\mathrm{pH}$ affected calcareous soil. Plant Physiol. Biochem. 104:284-293.

Ramzani, P.M.A., L. Shan, S. Anjum, W.-u.-D. Khan, H. Ronggui, M. Iqbal, Z.A. Virk, and S. Kausar. 2017. Improved quinoa growth, physiological response, and seed nutritional quality in three soils having different stresses by the application of acidified biochar and compost. Plant Physiol. Biochem. 116:127-138.

Rees, F., C. Germain, T. Sterckeman, and J.-L. Morel. 2015. Plant growth and metal uptake by a non-hyperaccumulating species (Lolium perenne) and a Cd-Zn hyperaccumulator (Noccaea caerulescens) in contaminated soils amended with biochar. Plant Soil 395:57-73.

Roberts, D.A., N.A. Paul, A.J. Cole, and R. de Nys. 2015. From waste water treatment to land management: Conversion of aquatic biomass to biochar for soil amelioration and the fortification of crops with essential trace elements. J. Environ. Manage. 157:60-68.

Roy, R.N., A. Finck, G.J. Blair, and H.L.S. Tandon. 2006. Plant nutrition for food security. A guide for integrated nutrient management. United Nations Food and Agriculture Organization Fertilizer and Plant Nutrition Bulletin 16. Food and Agriculture Organization of the United Nations. Rome, Italy.

Rudrappa, U. 2019. 26 Nov. 2019. <https://www. nutrition-and-you.com $/>$.

Sigua, G.C., J.M. Novak, D.W. Watts, K.B. Cantrell, P.D. Shumaker, A.A. Szögi, and M.G. Johnson.
2014. Carbon mineralization in two ultisols amended with different sources and particle sizes of pyrolyzed biochar. Chemosphere 103:313-321.

Sistani, K.R. and J.M. Novak. 2006. Trace metal accumulation, movement, and remediation in soils receiving animal manure, p. 689-706. In: M.N.V. Prasad, K.S. Sajwan, and R. Naidu (eds.). Trace elements in the environment: Biogeochemistry, biotechnology, and bioremediation. Taylor and Francis, Publ., CRC Press, Boca Raton, FL.

Sorrenti, G., C.A. Masiello, and M. Toselli. 2016. Biochar interferes with kiwifruit Fe nutrition in calcareous soil. Geoderma 272:10-19.

Subedi, R., C. Bertora, L. Zavattaro, and C. Grignani. 2017. Crop response to soils amended with biochar: expected benefits and unintended risks. Ital. J. Agron. 12(794):161-173.

Syuhada, A.B., J. Shamshuddin, C.I. Fauziah, A.B. Rosenani, and A. Arifin. 2016. Biochar as soil amendment: Impact on chemical properties and corn nutrient uptake in a Podzol. Can. J. Soil Sci. 96:400-412.

United Nations Food and Agriculture Organization (UN FAO). 2019. 21 Nov. 2019. <http:// www.fao.org/state-of-food-security-nutrition/ en $/>$.

United States Department of Agriculture (USDA). 2014. United States Department of Agriculture. Natural Resources Conservation Service. Soil Health Kit-Guidelines for Educators. Soil $\mathrm{pH}$. 25 Nov. 2019. < https://www.nrcs.usda.gov/Internet/ FSE_DOCUMENTS/nrcs142p2_051574.pdf $>$.

United States Environmental Protection Agency (US EPA). 1996. Method 3050B: Acid digestion of sediments, sludges, and soils. Revision 2. Washington, DC.

Wakefield Biochar. 2019. How to use biochar. 21 Nov. 2019. <https://www.wakefieldbiochar.com/ use-wakefield-biochar/>.

Welch, B.L. 1951. On the comparison of several mean values: An alternative approach. Biometrika 38:330-336.

White, J.D. 2018. The biochar mix. Grower talks. 21 Nov. 2019. <https:/www.growertalks.com/ Article $/$ ?articleid $=23562>$.

White, P.J. and P.H. Brown. 2010. Plant nutrition for sustainable development and global health. Ann. Bot. 105:1073-1080.

White, P.J., T.S. George, J.P. Hammond, and E.K. James. 2014. Improving crop mineral nutrition. Plant Soil 384:1-5. 